at Greenwich: Nov. 6d. 17h. 38.8m., 50 Aqr. $(D)$; Nov. 13d. $19 \mathrm{~h} .08 \cdot 9 \mathrm{~m} ., 104$ Tau. $(R)$; Nov. $16 \mathrm{~d}$. $02 \mathrm{~h} .53 \cdot 3 \mathrm{~m} ., 56 \mathrm{Gem} .(R)$; Nov. 16d. 05h. 46.2m., 61 Gem. $(R)$; Nov. 20d. 02h. 41.4m., 53 Leo. $(R)$. There is also an occultation of Saturn visible at Greenwich: Nov. 4d. 19h. 23.4m. (D); Nov. 4d. $19 \mathrm{~h} .42 \cdot 7 \mathrm{~m} .(R) . D$ and $R$ refer to disappearance and reappearance, respectively. The Taurid meteors are active during the first two weeks of November. Conditions for observation are favourable; the radiant is near R.A. $3 \mathrm{~h} .36 \mathrm{~m}$., Dec. $+14^{\circ}$. The Leonids are active during November 15-17, but conditions for observation are unfavourable.

\section{Royal College of Science and Technology, Glasgow}

The Royal College of Science and Technology, Glasgow, in consultation with the University Grants Committee, has appointed an Academic Advisory Committee. In the period of development ahead of the College, as outlined in the Government statement of May 1962, and pending the report of the Robbins Committee, the Advisory Committee will make available to the College its experience in developments both in Scotland and England. The terms of reference of the Advisory Committee will cover matters of general academic policy. The following are mombors of the Committee: Prof. E. L. Hirst, professor of organic chemistry, University of Edinburgh (chairman); Dr. Charles Wilson, vice-chancellor and principal of the University of Glasgow and lately vice-chancellor of the University of Leicester; J. O. Blair Cunynghame, deputy chairman of the Royal Bank of Scotland; Sir Lindor Brown, Waynflete professor of physiology, University of Oxford; Prof. J. Diamond, Beyer professor of mechanical engineering, University of Manchester; Prof. E. H. Phelps Brown, professor of economics of labour, London School of Economics; Prof. M. W. Thring, Newton Drew professor of fuel technology and chemical engineering, University of Sheffield; Dr. S. C. Curran, principal of the Royal College of Science and Technology, Glasgow.

\section{John Wiley and Interscience Publications: Dr. F. Betz, jun.}

Dr. Frederick Betz, jun., has been appointed to the editorial staff of John Wiley and Sons, Inc., New York, as editor in charge of the earth sciences and geography publications. He will be responsible for developing texts and reference books for the Wiley and Interscience imprints in the fields of geology, mineralogy, goophysics, meteorology, oceanography and geography. Since obtaining his Ph.D. from Princeton University in 1938, Dr. Betz has had varied exporiences. He was associated for seventeen yoars with the U.S. Geological Survey, in the United States and in Europe, and also has servod with tho U.S. Bureau of Mines, the Newfoundland Geological Survey, the Departmont of Geology of Lehigh University, and the Geological Socicty of America.

Macmillan and Co., Ltd. : Mr. B. J. Walby

Mr. BAsIL J. WALBY has joinod the editorial staff of Macmillan and Co., Ltd., London, to succood Mr. D. Grisewood, who has been appointed lecturer in mathematics in the Royal Univorsity of Malta. Mr. Walby will be responsible for scientific and technical books for secondary schools, technical colleges, universities, etc., published by Macmillan and Co. He read mathematics and chemistry at King's
College, London, and then spent two years as senior science instructor in the College of the Rhine Army. For four years after ho was assistant oditor of The Analyst and of Analytical Abstracts, and then carried out research in industrial mathematics with particular reference to computer applications at the Distillers' Co., Ltd. More recently, Mr. Walby has been acting as a management consultant in operational rosearch with SIGMA.

\section{Announcements}

Sir Geoffrey TAYLoR, formerly Yarrow research professor of the Royal Society of London, has been awarded the Franklin Medal of the Franklin Institute, Philadelphia, "for his manifold contributions to the knowledge of natural sciences".

Lond Hamsham, Minister for Science, is to open the new $£ 2$ million National Lending Library for Science and Technology at Boston Spa, Yorkshire, on November 5. The library collects all the world's literature of advanced science, technology and certain aspects of medicine, and promotes its use among industrial, agricultural and commercial organizations, universities and colleges, research institutes and hospitals throughout Britain. It has already amassed the largest scientific loan collection-at least 350,000 volumes - in Western Europe.

THE second Western National Meeting of the American Geophysical Union will be held at Stanford University, California, during December 27-29. Further information can be obtained from the American Geophysical Union, 1515 Massachusetts Avenue, N.W., Washington 5, D.C.

THE third Summer Research Institute of the Australian Mathematical Society will be held at the Australian National Univorsity, Canborra, during January 8-February 15, 1963, under the directorship of Prof. B. H. Neumann, of the Australian National University. Further information can be obtained from Dr. G. E. Wall, Department of Mathematics, University of Sydney.

THe fifteenth technical exhibition of the Oil and Colour Chemists' Association will be held in the Old and New Halls of the Royal Horticultural Society, London, during March 11-14. Further information can be obtained from the general secretary, R. H. Hamblin, Oil and Colour Chemists' Association, Wax Chandlers' Hall, Gresham Street, London, E.C.2.

A meeting on "Questioned Document Examination", in conjunction with the third international meeting on "Forensic Immunology, Medicine, Pathology and Toxicology", will be held at tho School of Pharmacy, London, during April 16-24. Topics under discussion will include: writing materials: paper, instruments, inks; laboratory examinations: chomical, photographical, optical; recent advances and problems in questioned document examinations; the role of the questioned documont cxaminor as an expert witness. Further information can be obtained from the Socretariat (Q.D.), Third International Meeting in Forensic Immunology, Medicine, Pathology and Toxicology, 28 Portland Place, London, W.1.

ERratum. In the fourth paragraph of tho articlo by Dr. A. Compton entitled "Effect of Feeding X-ray Irradiated Coliform Bacilli to Tumour-bearing Mice", which appeared on p. 1273 of the September 29 issuo of Nature, the last sentence should read: "It may be viewed ... graft tumours are known to grow as a rule not so well in older, larger animals ${ }^{4}$ ". 